\title{
Frequency of free-stall occupancy by dairy cows
}

\author{
Frequência de ocupação em free-stall por vacas leiteiras \\ Daiane Cecchin - Alessandro Torres Campos • \\ Tadayuki Yanagi Junior • Maria de Fátima Ávila Pires • \\ Dian Lourençoni - Francine Aparecida Sousa - Diego Cecchin
}

D Cecchin (Corresponding author) - AT Campos - T Yanagy Junior - D Lourençoni - FA Sousa - D Cecchin Universidade Federal de Lavras (UFLA), Lavras, MG, Brasil.

email: daianececchin@yahoo.com.br

\author{
MFA Pires \\ Empresa Brasileira de Pesquisa Agropecuária, Embrapa \\ Gado de leite
}

Diego Cecchin

Especialista em Gestão

Recebido: 19 de Agosto, 2015 - Revisado: 22 de Setembro, 2015 - Aceito: 28 de Setembro, 2015

\begin{abstract}
The objective of the present study was to evaluate the behavior of dairy cows confined in free-stall systems. Eighteen Holstein cows were evaluated in this research. The following frequencies were evaluated at 10-min intervals: stall occupancy, corridor occupancy, feeding, moving and being milked. The free-stalls were covered with rubber mattresses. Thermal variables such as dry bulb temperature, humid bulb temperature, black globe temperature and air velocity were recorded hourly. The data collections were made for 13 days in May, during autumn. Dynamics of social hierarchy was observed for 18 animals. The animals preferred to occupy the stalls located in quadrant 1 , between the north and east axis, where there was less movement of people, tractors and vehicles. The cows occupied the freestalls during the early morning and feeding occupancy was higher during the morning. Higher temperatures in the afternoon caused the longer occupation of the corridors by the cows during this period. Some dairy cows housed in a free-stall barn expressed dominant and/or hierarchical behaviors.
\end{abstract}

Keywords: behavior, occupancy rate, rubber mattress

\section{Introduction}

The social behavior of dairy cattle is considered one of the main indicators of animal welfare (Bond et al 2012), and its study has the advantage of being non-invasive (Castro et al 2011). Faria et al (2011) define animal behavior as the reactions of the animal in relation to its surroundings. In turn, animal welfare is defined as the state of harmony between
Resumo O objetivo do presente estudo foi avaliar o comportamento de vacas leiteiras em confinamento tipo freestall. Dezoito vacas holandesas foram avaliadas nessa pesquisa. As seguintes frequências foram avaliadas aos 10 minutos de intervalo: ocupação da baia, ocupação do corredor, alimentação, movimentação e sendo ordenhada. As baias estavam recobertas com colchões de borracha. As variáveis ambientais, como temperatura de bulbo seco, temperatura de bulbo úmido, temperatura de globo negro e velocidade do ar foram registradas a cada hora. As coletas foram realizadas durante 13 dias em maio, durante o outono. A dinâmica da hierarquia social foi observada para 18 animais. Os animais preferiram ocupar baias localizadas o quadrante 1 entre o Norte e o eixo leste, onde havia menos movimentação de pessoas, veículos e tratores. As vacas ocuparam mais as baias durante o período da madrugada e se alimentaram por mais tempo durante o período da manhã. Temperaturas mais elevadas no período da tarde fizeram com que as vacas ocupassem por mais tempo o corredor no período. Algumas vacas alojadas expressaram comportamentos dominantes e/ou hierárquicos.

Palavras-chave: comportamento, colchão de borracha, taxa de ocupação

the animal and the environment in which it is inserted, and is characterized by physical and physiological conditions (Jesus 2009). The study of animal welfare is imperative for the animal production sector (Camerini and Nascimento 2012).

Cattle establish a hierarchical status within a structured group through aggressive and or agonistic interactions. These interactions in turn, can demonstrate that the animal has priority in certain environmental or structural 
features over other animals in the herd. This behavior should be considered when designing an installation or establishing the management techniques to be adopted, because space or food constraints exist, and for example, increase the possibility of disputes between the animals. Studies conducted by De Vries and Von Keyserlingk (2006) showed that increasing the density of animals in the feeding area caused an increase in the number of agonistic interactions between animals.

According to Paranhos da Costa and Costa-e-Silva (2007), the factors that typically determine the position in the hierarchy are the weight, age and breed of animals, and the time required for the establishment of the hierarchy in a newly formed herd will depend on the number of animals and the farming system.

The confinement of animals emerged as an alternative to increase productivity, providing new opportunities to manage dairy herds in a greater degree of comfort; however, new problems arose in consequence of confinement (Perissinotto et al 2009). The material used for bedding can be considered as one of these problems, when it is not appropriate. According to Mitev et al (2012), the bed should be comfortable enough to ensure a proper rest and welfare for the animals. According to Castro et al (2013), the use of new building materials might improve the environment inside the premises; however, studies relating to the environment and welfare, warn that actions should be taken to prevent any production losses related to these materials.

Mitev et al (2012) reported that the type of material using on bedding greatly influences the time that the animal remains lying down, which is important, as it minimizes the stress on the legs, reducing the occurrence of lameness. This reduction favors milk production, since it results in an increase in blood flow to the mammary gland and in ruminating time, increasing the consumption of food. The reduction in the time that cows spend resting can result in physiological changes associated with stress, which can affect the health and production. According to Carreira et al (2009), the following activities are characteristics of dairy cows that are housed in free-stall barns: lying in stalls, feeding, drinking water and moving along the corridors or being milked.

Several factors related to the individual characteristics of the animal, management and design of the facilities can affect the behavior and the time spent in stall occupancy. (Careira et al 2009). The size and type of bedding used in free-stall can strongly affect the behaviors of "standing" and "lying", the frequency of lesions in the hooves, hocks and knees, as well as the occurrence of mastitis (Boone et al 2009). Appropriately sized stall allow animals to express a variety of natural behaviors, including locomotion, with positive implications on the social environment among animals. In turn, facilities with inappropriate dimensions exacerbate competition for resources (food, water and rest areas), which is a disturbance factor that can generate aggressive behavior and social instability in the herd (Cerqueira et al 2011). Thus, the welfare of confined animals depends on the care and attention given (Camerini and Nascimento, 2012) and the environment where the animals are housed.

The objective of this study was to analyze the behavioral patterns of free-stall occupancy by dairy cows.

\section{Material and Methods}

The study was conducted on the facilities of the Sistema Intensivo de Produção de Leite (SIPL) (Intensive System of Milk Production), at the Embrapa Gado de Leite, in the city of Coronel Pacheco, Zona da Mata, Minas Gerais, Brazil, located at a latitude of $21^{\circ} 33$ '22" South and a longitude of $43^{\circ} 06^{\prime} 15^{\prime \prime}$ West, at an altitude of $414 \mathrm{~m}$. The climate of the region, according to the Köppen classification, is Cwa, i.e., hot weather, rainy temperate, with a dry winter and a hot and rainy summer.

\section{Experimental Shed}

The experiment was conducted in a free-stall confinement shed, $37.1 \mathrm{~m}$ long, $36.0 \mathrm{~m}$ wide, $7.0 \mathrm{~m}$ high in the center and with $3.5 \mathrm{~m}$ headway, with the capacity to accommodate 80 adult animals, divided into four areas, with one wing used for data collection (consisting of 18 animals).

The shed had the following characteristics: openings on four sides, pillars of precast concrete, a slotted concrete floor for better water drainage and waste, a central corridor for feeding (4.5 m wide) and a corridor to conduct the cows to the milking parlour (4.1 m length).

The roofing consisted of fiber cement roofing tiles with the ridge area unroofed, to provide ventilation by the thermosiphon effect. The ridge were closed with asbestos roofing tiles installed in a vertical orientation, to reduce the incidence of direct solar radiation inside the facility.

Twenty individual beds were installed in a wing of the free-stall barn (Figure 1). The beds were full with rubber rollers that were filled with a chopped byproduct from vulcanized tires and were installed in each stall. The spaces between the rollers were also filled with the same material. A polyester canvas was used to cover the bed and for the manufacture of the rollers.

Animals and management

Eighteen high-production multiparous pure Holstein cows, with a mean milk yield of $29.2 \pm 7.77 \mathrm{~kg} \mathrm{day}^{-1}$ and a mean body weight of $560 \pm 64.1 \mathrm{~kg}$ were observed. The bulky feed consisted of corn silage and $2 \mathrm{~kg}$ Tifton (Cynodon 
nlemfuensis) chopped per animal/day, in order to increase the fiber content in the feed and thereby to reduce the incidence of acidosis. The concentrate supplied (13 kg animal/day) contained $22 \%$ of crude protein $(\mathrm{CP})$ with the addition of $100 \mathrm{~g}$ of sodium bicarbonate. The feed was provided at the following times: 07:00 am, 10:00 am, 02:00 pm, 04:00 pm, 09:00 pm, and water was available ad libitum. Milking was performed three times daily, at 05:30 am, 01:00 pm and 09:00 pm in a herring bone milking parlor adjacent to the free-stall.

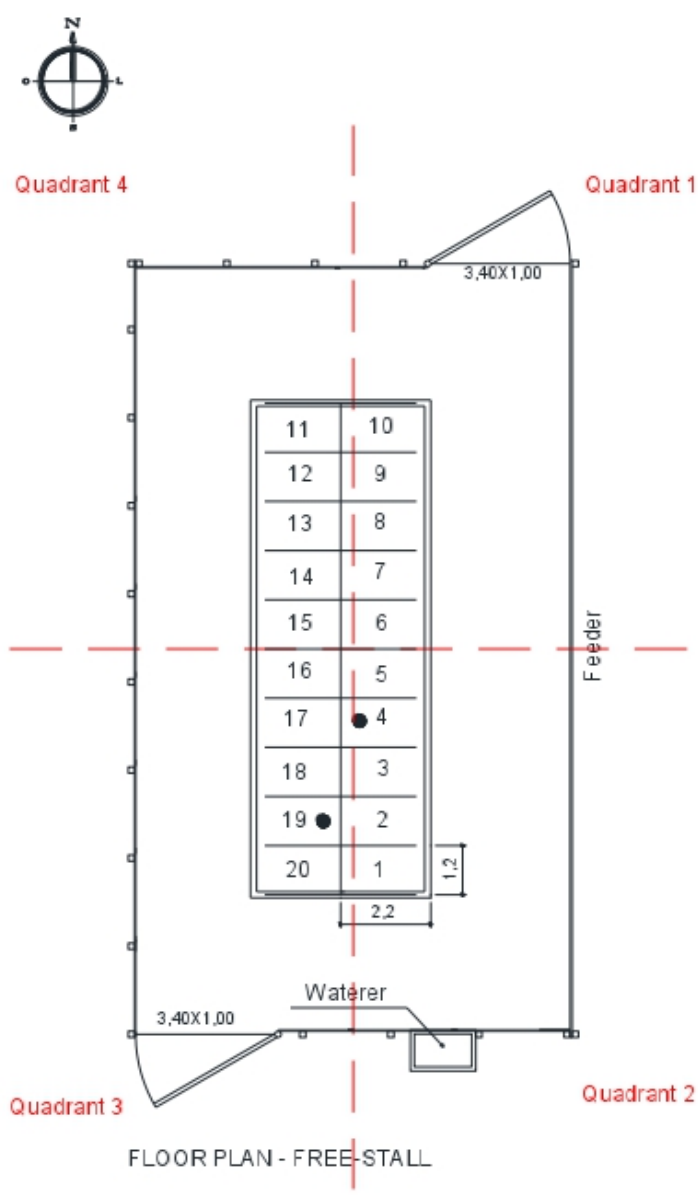

Figure 1 Scheme of the wing used in the experiment.

Meteorological data measurements

Black globe with 0.15-m-diameter hollow copper spheres placed together the thermo-hygrometer (model 5203.03.0.00 - ICOTERM) were installed to determine the dry and wet bulb temperature in bays 4 (quadrant 4) and 19 (quadrant 3) and in the solarium (Figure 1), at a height of $0.70 \mathrm{~m}$ above the ground. The wind velocity was determined using a digital anemometer, (Model NA-3090, Icel, Manaus, Brazil). These meteorological data were collected hourly. The black globe-humidity index (BGHI) were calculated from the obtained data using the following equation, proposed by Buffington et al (1981):
$\mathrm{BGHI}=\mathrm{Bgt}+0.36 \mathrm{Dpt}-330.08$

where Bgt is the black globe temperature $(\mathrm{K})$ and Dpt is dew-point temperature $(\mathrm{K})$.

\section{Behavioral description and measurements}

The animal behavior data were collected during alternating periods of six hours: morning (06:00 am to 11:50 am; afternoon (12:00 pm to 05:50 pm), night (06:00 pm to $11: 50 \mathrm{pm})$ and dawn and early morning (12:00 am to 05:50:00 am).

The behavioral data were collected by visual assessment (scan sampling) every ten minutes (seven samples/ period) during each period, by observing the following activities: stall occupancy, feeding, corridor occupancy, being milked and moving. The animal was considered occupying the stall when it was lying inside the stall or standing on the bed, according to the observations of Mitev et al (2012) that before lying down, cows usually rest for a few minutes on the site chosen for lying.

Statistical analysis

Statistical descriptive analysis of the data was performed via frequency graphs, and the creation of tables with average, medium, maximum and minimum values.

\section{Results and Discussion}

Among the behavioral variables, stall occupancy was the most frequent behavior $(55.80 \%)$. According to Boone (2009), dairy cows spend about half of their lives lying down, with a mean of 12 to $14 \mathrm{~h} \mathrm{day}^{-1}$. A reduction in resting time can result in physiological changes that affect the health and productivity of animals. Munksgaard et al (2005) reported that resting has a high priority in the physiology of cows, since they spend more time resting than feeding.

The second most frequent activity was feeding (Figure 2), with a mean frequency of $25.99 \%$ of the time, followed by standing in the corridors with $11.15 \%$, being milking with $6.11 \%$ and moving with $1.11 \%$.

The stalls remained occupied for longer periods in the early morning with a mean frequency of $73.38 \%$, followed by at night with a frequency of $57.41 \%$, possibly because the ambient temperature was below the limit for comfort (Figure 3 ), and there was less external stimulus. Dairy cows spent most of their time lying down (8-14 h), and rest time is very important for the dairy activity when animals are confined in free-stall (Careira et al 2009). According to Passini et al (2009), cows lying down and ruminating express a condition of comfort and welfare, and possibly security provided by the previously defined hierarchy. 


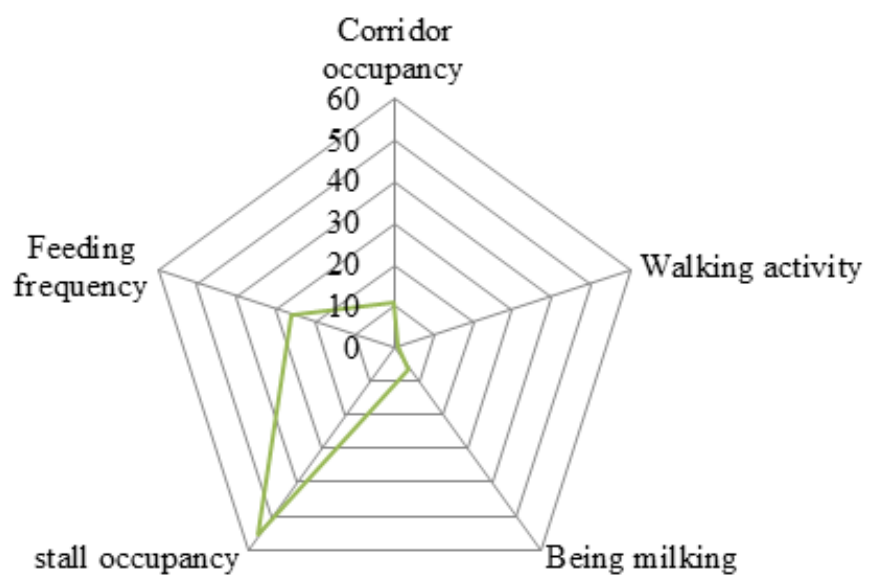

Figure 2 Frequency of occurrence for evaluated behavior.

The demand for food was synchronous with the hours when food was offered and with the hours after milking. The animals spent more time feeding in the morning (Figure 4B), followed by afternoon, possibly due the milking and the availability of feed for the animals. The periods of the day influence the feeding behavior of cows (Silva et al 2010). Pereira et al (2011) observed more food intake during the day, more frequently in the morning and Pinto et al (2010), who studied young crossbred bulls in confinement, found a higher frequency of food intake in the period from $12: 15 \mathrm{pm}$ to $06: 00 \mathrm{pm}$, due to the greater availability of food. Fraser and Broom (1990) reported that cows that are housed in stables spend about five hours feeding, with a diurnal feeding rhythm.

Table 1 Value Minimum, mean, medium and maximum frequencies for each activities (of corridor occupancy, feeding frequency, stall occupancy, being milking, walking activity). All amounts in \%.

\begin{tabular}{lccccc}
\hline \multirow{3}{*}{ Corridor occupancy } & & Min. & Ave. & Med. & Max. \\
& Early morning & 0.40 & 8.17 & 7.14 & 20.33 \\
& Morning & 6.75 & 12.78 & 11.90 & 27.64 \\
& Afternoon & 7.54 & 13.98 & 13.89 & 28.17 \\
& Night & 3.97 & 9.66 & 8.33 & 20.24 \\
\hline \multirow{3}{*}{ Feeding frequency } & Early morning & 2.08 & 8.00 & 8.70 & 13.89 \\
& Morning & 33.73 & 42.02 & 42.46 & 54.76 \\
& Afternoon & 22.22 & 30.18 & 30.26 & 39.29 \\
& Night & 19.44 & 23.74 & 23.41 & 31.35 \\
\hline \multirow{3}{*}{ Stall occupancy } & Early morning & 63.10 & 73.38 & 71.43 & 85.71 \\
& Morning & 26.19 & 44.27 & 44.84 & 57.94 \\
& Afternoon & 35.71 & 48.13 & 48.02 & 61.9 \\
& Night & 46.83 & 57.41 & 58.33 & 68.25 \\
\hline \multirow{2}{*}{ Being milking } & Early morning & 9.13 & 9.61 & 9.52 & 10.32 \\
& Morning & 0.00 & 0.02 & 0.00 & 0.04 \\
& Afternoon & 4.66 & 6.7 & 6.35 & 8.40 \\
& Night & 6.75 & 8.18 & 8.13 & 9.52 \\
\hline \multirow{2}{*}{ Walking activity } & Early morning & 0.00 & 0.84 & 0.40 & 2.38 \\
& Morning & 0.00 & 0.90 & 0.79 & 2.38 \\
& Afternoon & 0.00 & 1.02 & 0.79 & 5.16 \\
& Night & 0.00 & 1.01 & 0.59 & 6.35 \\
\hline
\end{tabular}


The mean BGHI was lower on the observed days (Figure 3) than the values established by the National Weather Service (1984), considering the following ranges for the BGHI: up to 74 indicates a comfort condition for cattle; between 75 and 78 the situation requires attention; from 79 to 84 represents danger, and above 84 is an emergency situation. The highest mean values of BGHI within the facility were recorded in the afternoon between 03:00 pm and 05:00 pm $(59 \pm 6.42)$, whereas in the solarium (outside the facility), they were observed between 11:00 am and 12:00 am $(65 \pm 9.11)$.
The animals occupied the corridors for the longest periods in the afternoon (13.98 h) as can be seen in Figure $4 \mathrm{C}$, possibly because the $\mathrm{BGHI}$ in this period was higher compared to in other periods (Figure 3), causing the animal to spend more time standing in the corridor to improve the efficiency of heat dissipation, since Bewley et al (2009) suggested that cows spend more time standing to increase heat loss by increasing the amount of skin exposed to air flow or wind. This result corroborates the finding of Schütz (1984), who observed that the percentage time that cows spend standing increases as the temperature increases.

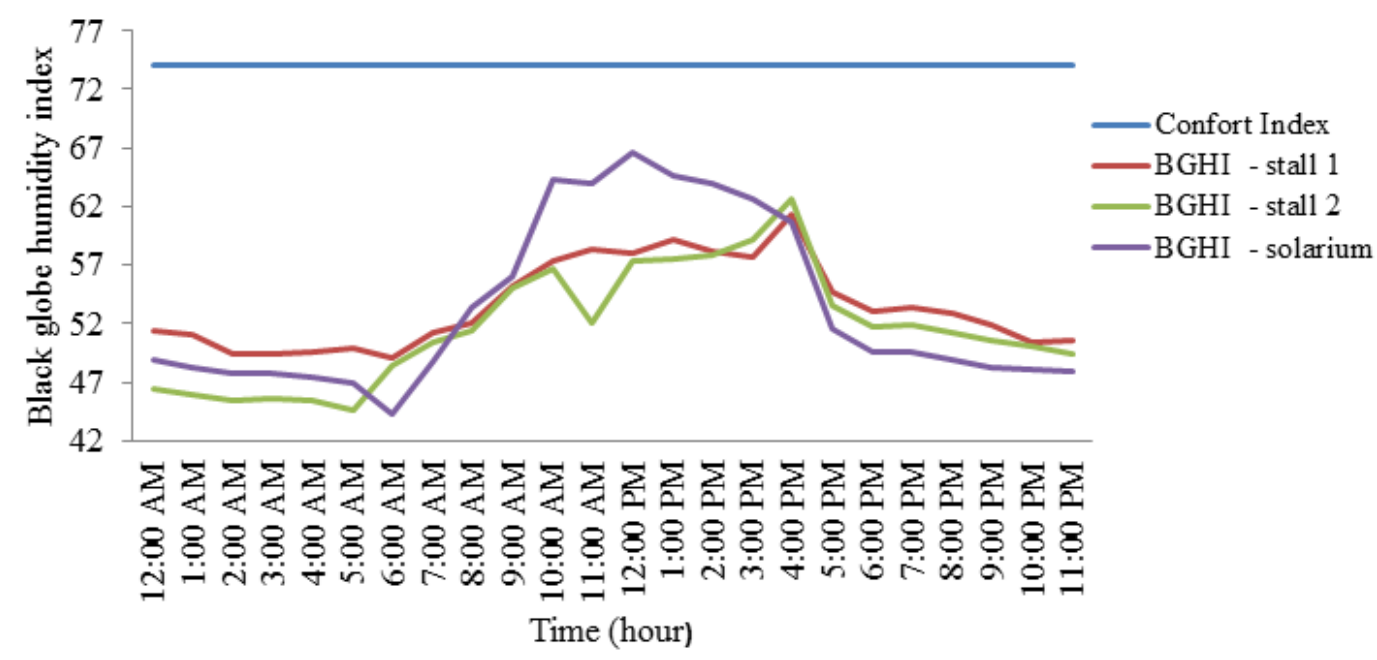

Figure 3 Mean value of the black globe-humidity index (BGHI) inside and outside the facility and comfort indices.

Little locomotion by the animals was recorded (Figure 4D), possibly because the observations were made every 10 min and it was considered that the animal remained in the same activity state for the rest of the time until the next assessment.

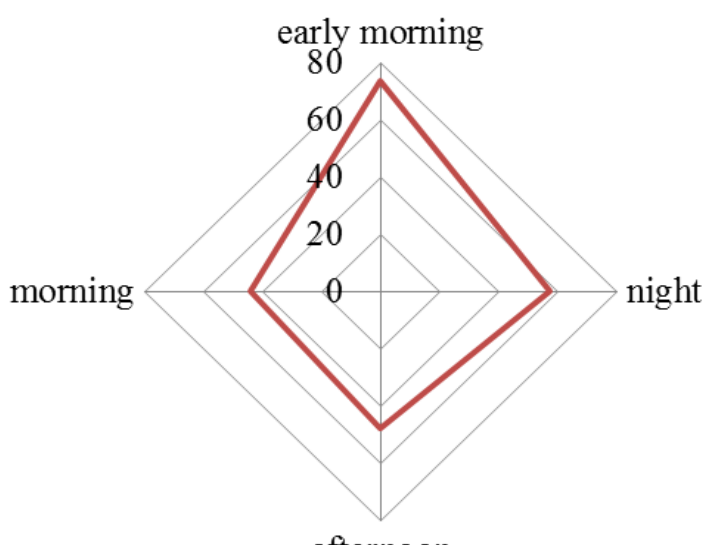

A
The milking occurred during the early morning, afternoon and night (Figure 4E), due to the chosen management.

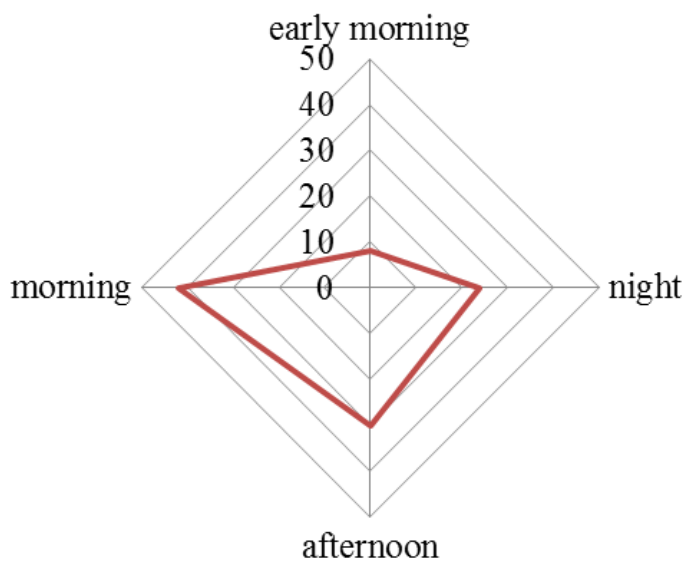

B 


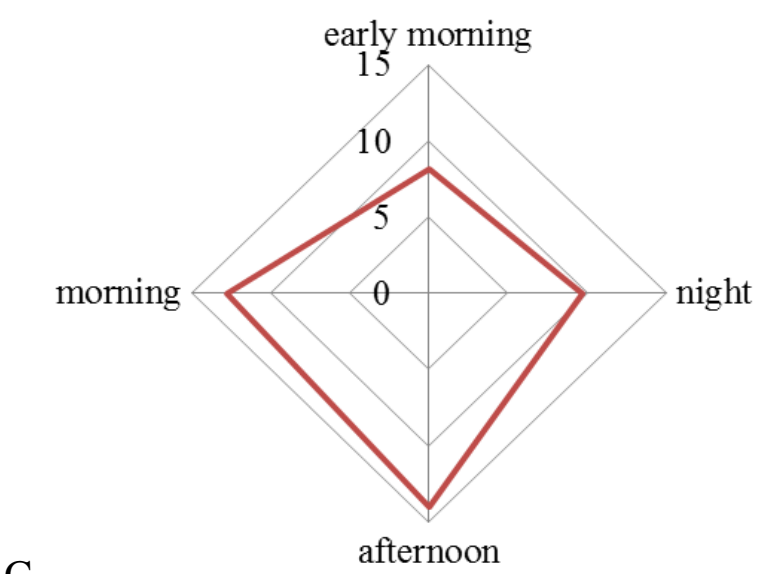

C

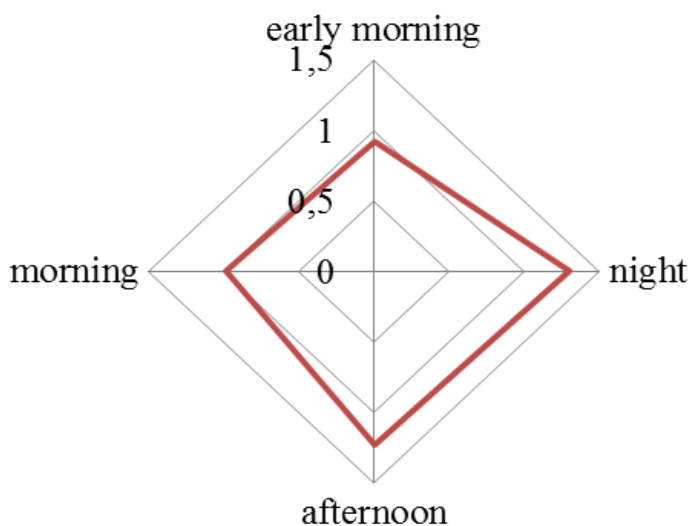

$\mathrm{D}$

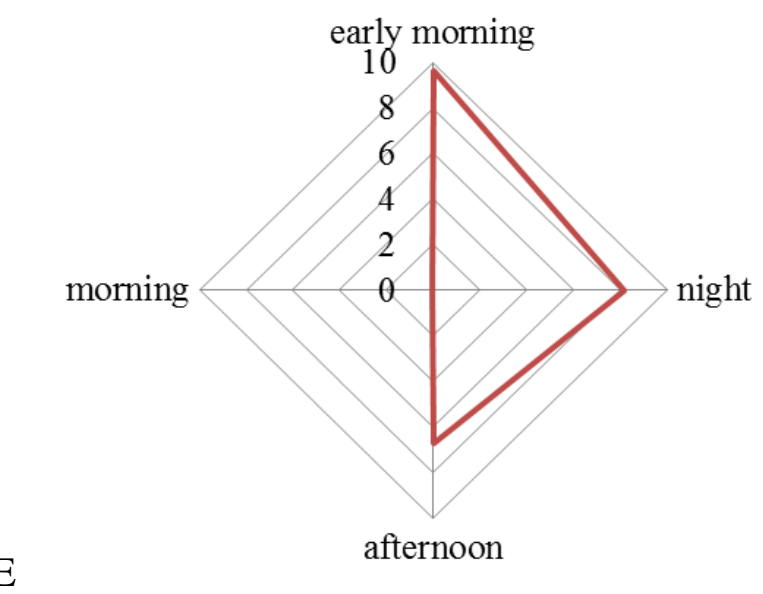

Figure 4 The frequency of occurrence of the behavior of Holstein dairy cows: (A) stall occupancy, (B) feeding frequency, (C) corridor occupancy, (D) walking activity, and (E) being milking.

Some animals had higher occupancy rate at certain stalls, thus expressing a preference for certain stall the rather than of others. Moreover, dominance behavior was observed as aggressiveness when certain stalls were occupied by certain animals, which even resulted in stalls being vacated by the dominated animals. Cows $6,8,14$ and 16 showed notable dominant behavior.

Among the eighteen observed cows, more of half of the group (Table 2 and Figure 5) preferred to occupy stalls located in quadrant 1 with the following frequencies: (cow 1 - 34.31\%; 2 - 37.39\%; 3 - 37.39\%; 5 - 27.18\%; 7 - 35.07 $\% ; 8-41.68 \% ; 10-47.16 \% ; 11-47.89 \% ; 15-36.27 \%$ and $16-56.62 \%)$. Four cows showed a preference for quadrant 4 (cow $9-39.31 \% ; 12-25.25 \% ; 13-66.14 \%$ and $18-$ $79.09 \%$ ), three for quadrant 3 (cows $4-41.89 \%$; $14-$ $52.93 \%$ and $17-35.13 \%$ ) and two preferred quadrant 2 (cows $3-35.53 \% 6-47.52 \%$ ). The preference for quadrant 1 might be because these stalls were located in a part of the wing with a lower activity of people, vehicles and tractors. The animals had no access to stalls 4 and 19, since these contained equipment used for the measurement of thermal environment data.

\section{Conclusions}

Some dairy cows housed in a free-stall barn expressed dominant and/or hierarchical behaviors. The animals preferred to occupy the stalls that were located in the part of the wing with a lower activity of people, vehicles and tractors. The stalls occupancy and feeding occurred primarily at early morning and in the morning, respectively. During afternoon, the dairy cows remained for a longer period in the corridors due to the increase in air temperature.

\section{Acknowledgments}

We thank EMBRAPA Gado de Leite (Dairy Cattle) for granting the facilities for performing this experiment. We also, thank CAPES and CNPq for financial support for the development of this research. 
Table 2 Average stall occupancy frequencies for animal in each period.

\begin{tabular}{|c|c|c|c|c|c|c|c|c|c|c|c|c|c|c|c|c|c|c|c|c|}
\hline \multirow[b]{3}{*}{ Animals } & \multicolumn{20}{|c|}{ Stalls } \\
\hline & \multicolumn{5}{|c|}{ Quadrant2 } & \multicolumn{5}{|c|}{ Quadrant1 } & \multicolumn{5}{|c|}{ Quadrant4 } & \multicolumn{5}{|c|}{ Quadrant 3} \\
\hline & 1 & 2 & 3 & 4 & 5 & 6 & 7 & 8 & 9 & 10 & 11 & 12 & 13 & 14 & 15 & 16 & 17 & 18 & 19 & 20 \\
\hline 1 & 1.47 & 10.46 & 7.89 & 0.00 & 1.65 & 10.09 & 10.09 & 7.71 & 2.02 & 4.40 & 0.00 & 1.10 & 1.65 & 6.79 & 10.83 & 1.47 & 10.09 & 5.32 & 0.00 & 6.97 \\
\hline 2 & 7.28 & 8.32 & 7.80 & 0.00 & 12.13 & 0.69 & 6.24 & 4.51 & 2.25 & 10.57 & 6.76 & 0.52 & 10.05 & 8.32 & 4.68 & 3.47 & 2.43 & 3.64 & 0.00 & 0.35 \\
\hline 3 & 0.00 & 7.95 & 2.03 & 0.00 & 4.40 & 5.58 & 7.95 & 14.72 & 6.26 & 2.88 & 4.40 & 14.38 & 2.88 & 3.05 & 6.43 & 13.71 & 0.85 & 2.54 & 0.00 & 0.00 \\
\hline 4 & 1.01 & 3.18 & 2.68 & 0.00 & 3.18 & 1.68 & 0.84 & 5.70 & 0.67 & 0.00 & 6.37 & 7.54 & 8.38 & 10.05 & 6.87 & 6.37 & 22.95 & 10.39 & 0.00 & 2.18 \\
\hline 5 & 2.75 & 8.58 & 8.90 & 0.00 & 5.66 & 7.77 & 7.93 & 3.24 & 5.18 & 1.46 & 6.47 & 10.03 & 0.00 & 7.77 & 2.91 & 4.69 & 6.15 & 8.25 & 0.00 & 2.27 \\
\hline 6 & 2.86 & 15.65 & 12.60 & 0.00 & 16.41 & 5.53 & 9.35 & 2.29 & 2.10 & 1.72 & 0.00 & 1.15 & 4.20 & 0.00 & 4.77 & 6.68 & 2.67 & 4.01 & 0.00 & 8.02 \\
\hline 7 & 2.80 & 8.02 & 6.16 & 0.00 & 4.10 & 14.37 & 5.22 & 6.34 & 5.22 & 3.92 & 0.00 & 1.12 & 2.80 & 1.12 & 4.85 & 3.73 & 11.94 & 8.02 & 0.00 & 10.26 \\
\hline 8 & 3.61 & 3.81 & 7.01 & 0.00 & 2.00 & 9.22 & 2.40 & 3.41 & 22.04 & 4.61 & 4.81 & 0.60 & 5.41 & 5.61 & 2.81 & 8.42 & 0.20 & 9.42 & 0.00 & 4.61 \\
\hline 9 & 1.05 & 1.40 & 3.16 & 0.00 & 11.23 & 3.68 & 6.14 & 8.77 & 10.35 & 7.37 & 2.28 & 8.60 & 14.04 & 4.39 & 10.00 & 6.32 & 1.23 & 0.00 & 0.00 & 0.00 \\
\hline 10 & 0.17 & 6.33 & 9.50 & 0.00 & 6.17 & 15.83 & 16.00 & 6.00 & 3.50 & 5.83 & 0.00 & 6.33 & 5.67 & 6.00 & 5.83 & 0.17 & 0.83 & 3.00 & 0.00 & 2.83 \\
\hline 11 & 8.81 & 3.64 & 10.54 & 0.00 & 0.77 & 4.60 & 4.98 & 6.32 & 13.41 & 18.58 & 0.19 & 6.51 & 1.92 & 0.00 & 0.19 & 4.60 & 5.36 & 6.32 & 0.00 & 3.26 \\
\hline 12 & 3.68 & 17.39 & 6.35 & 0.00 & 4.68 & 7.02 & 3.18 & 4.68 & 3.85 & 0.00 & 2.51 & 8.36 & 5.85 & 3.68 & 4.85 & 6.86 & 3.34 & 13.55 & 0.00 & 0.17 \\
\hline 13 & 0.69 & 0.00 & 3.13 & 0.00 & 1.22 & 0.17 & 1.04 & 0.00 & 0.00 & 0.00 & 0.00 & 2.60 & 1.91 & 24.13 & 37.50 & 7.29 & 19.10 & 1.22 & 0.00 & 0.00 \\
\hline 14 & 0.89 & 0.53 & 0.00 & 0.00 & 2.85 & 1.96 & 7.49 & 4.28 & 8.02 & 0.00 & 4.10 & 2.14 & 5.35 & 4.28 & 5.17 & 19.07 & 3.21 & 7.66 & 0.00 & 22.99 \\
\hline 15 & 1.65 & 7.44 & 9.59 & 0.00 & 4.96 & 6.12 & 8.76 & 4.30 & 13.55 & 3.64 & 3.47 & 6.78 & 0.00 & 0.00 & 1.16 & 2.64 & 13.06 & 4.63 & 0.00 & 8.26 \\
\hline 16 & 0.71 & 8.82 & 2.12 & 0.00 & 0.18 & 21.87 & 11.11 & 11.29 & 9.70 & 2.65 & 0.00 & 0.00 & 3.00 & 2.65 & 4.23 & 1.59 & 7.76 & 8.11 & 0.00 & 4.23 \\
\hline 17 & 1.79 & 1.43 & 7.17 & 0.00 & 0.72 & 1.61 & 1.25 & 6.45 & 11.47 & 12.37 & 9.68 & 5.73 & 3.58 & 0.00 & 1.61 & 7.71 & 2.15 & 8.24 & 0.00 & 17.03 \\
\hline 18 & 5.12 & 2.46 & 1.43 & 0.00 & 0.00 & 0.00 & 0.82 & 1.43 & 0.00 & 0.00 & 0.82 & 26.02 & 27.25 & 23.77 & 1.23 & 3.89 & 2.05 & 3.28 & 0.00 & 0.41 \\
\hline
\end{tabular}




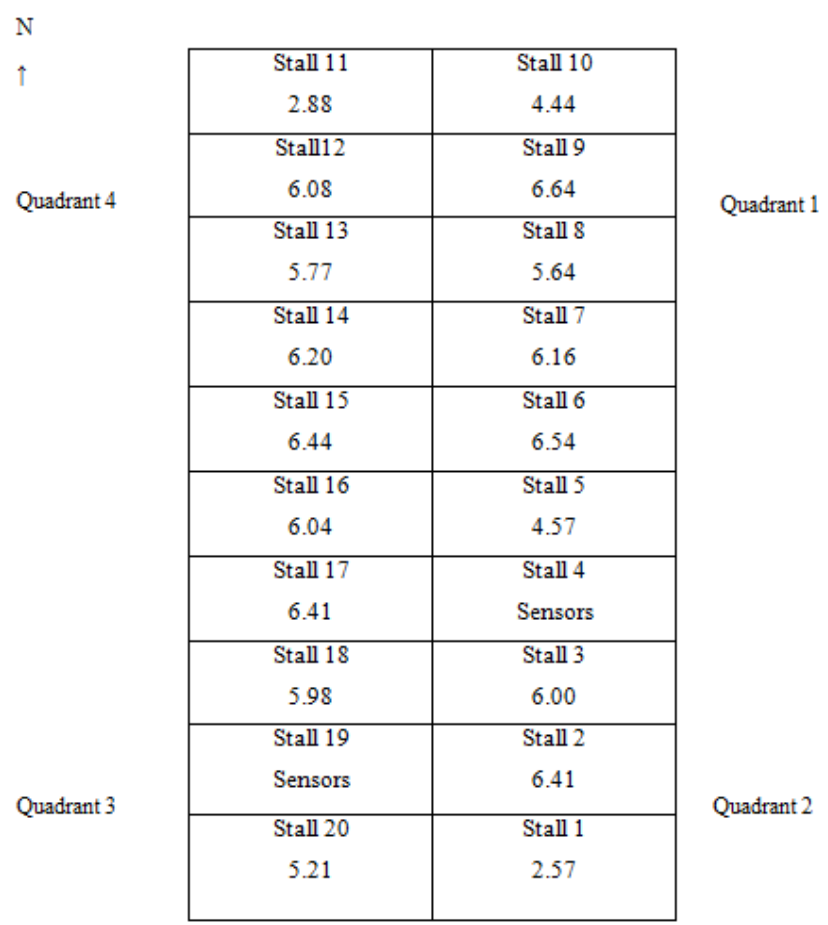

Figure 5 Average of Stall occupancy frequency for each stall (\%) for the eighteen Holstein dairy cows.

\section{References}

Bewley JM, Boyce RE, Hockin J, Munksgaard L, Eicher SD, Einstein ME, Schutz MM (2009) Influence of milk yield, stage of lactation, and body condition on dairy cattle lying behaviour measured using an automated activity monitoring sensor. Journal of Dairy Science 76:1-6.

Bond GB, Almeida R, Ostrensky A, Molento CFM (2012) Métodos de diagnóstico e pontos críticos de bem-estar de bovinos leiteiros. Ciência Rural 42:1286-1293.

Boone R, Bucklin R, Bray D (2009) Comparison of freestall bedding materials and their effect on cow behavior and cow health. American Society of Agricultural Engineers - ASAE 2:739-757.

Buffington DE, Collazo Arocho A, Canton GH, Pitt D (1981) Black globe humidity index (BGHI) as a comfort equation for dairy cows. Trans. ASAE 24:711-714.

Camerini NL, Nascimento JWB (2012) Análise da influência do revestimento de resíduo de EVA no conforto térmico de instalações agropecuárias. Revista Eletrônica de Materiais e Processos 7:48-51.

Carreira XC, Fernández ME, Mariño RA (2009) Indices for estimation of dairy free-stall occupancy. Applied Animal Behaviour Science 119:23-31.

Castro JO, Campos AT, Ferreira RA, Yanagi Júnior T, Tadeu HC (2011) Uso de ardósia na construção de celas de maternidade: I efeito sobre o ambiente e comportamento de suínos. Engenharia Agrícola 31:458-467.

Castro JO, Ferreira RA, Campos AT, Ferreira RA, Yanagi Júnior T, TADEU HC (2013) Uso de ardósia na construção de celas de maternidade para suínos: II - ambiente térmico e avaliação dos ruídos. Engenharia Agrícola 33:37-45.

Cerqueira JL, Araújo JP, Sorensen, JT, Ribeiro, JN (2011) Alguns indicadores de avaliação de bem-estar em vacas leiteiras - revisão. Revista Portuguesa de Ciências Veterinárias 110:577-580.
Devries TJ, Von Keyserlingk MAG (2006) Feed stalls affect the social and feeding behavior of lactating dairy cows. Journal Dairy Science 89:3522-3531.

Faria LAN, Barbosa OR, Zeoula LM, Aguiar SC, Prado RM, Bertolini DA (2011) Produto à base de própolis (LLOS) na dieta de bovinos inteiros confinados: comportamento animal e respostas sanguíneas. ActaScientiarum. Animal Sciences 33:79-85.

Fraser AF, Broom DM (1990) Farm animal behaviour and welfare. 3rd ed. London: BailliereTindall. 437 p.

Jesus RS (2009) Comportamento de novilhas gir e girolandas leiteiras em sistema silvipastoril no semi-árido sergipano. São Cristóvão: UFS. Dissertação Mestrado.

Mitev J, Varlyakov I, Miteva T, Vasilev N, Gergovska J, Uzunova K, Dimova V (2012) Preferences of freestall housed dairy cows to different bedding materials. Journal of Faculty of Veterinary Medicine 38:135-140.

Munksgaard L, Jensen MB, Pedersen LJ, Hansen ST, Matthews L (2005) Quantifying behavioural priorities: effects of time constraints on behaviour of dairy cows, Bos taurus. Applied Animal Behaviour Science 92:3-14.

Naticonal Weather Service. Heat stress index, AKA apparent temperature Techical Attachament, p. 84-11, 1984.

Paranhos da Costa M \& Costa-e-Silva EV (2007) Aspectos básicos do comportamento social de bovinos. Revista Brasileira Reprodução Animal 31:172-176.

Passini, R, Ferreira FA, Borgatti LMOP, Terêncio H, Souza RTYB, Rodrigues PHM (2009) Estresse térmico sobre a seleção da dieta por bovinos. Acta Scientiarum. Animal Sciences 31:303-309.

Pereira ES, Pimentel PG, Carneiro MSS, Mizubuti IY, Ribeiro ELA, Junior JNR, Costa MRGF (2011) Comportamento ingestivo 
de vacas em lactação alimentadas com rações a base de torta de girassol. Semina: Ciências Agrárias 32:1201-1210.

Perissinotto M, Moura DJ, Cruz VF, Souza SL, Lima KAO, Mendes AS (2009) Conforto térmico de bovinos leiteiros confinados em clima subtropical e mediterrâneo pela análise de parâmetros fisiológicos utilizando a teoria dos conjuntos fuzzy. Ciência Rural 39:1492-1498.

Pinto AP, Marques JA, Abrahão JJS, Nascimento WG, Costa MAT, Lugão SMB (2010) Comportamento e eficiência ingestiva de tourinhos mestiços confinados com três dietas diferentes. Archivos de Zootecnia 59:427-434.

Shultz TA (1984) Weather and shade effects on cow corral activities. Journal of Dairy Science 67:868-873.

Silva EVCE, Katayama KA, Mace GG, Rueda PM, Abreu UGP, Ari CESNZ (2010) Efeito do manejo e de variáveis bioclimáticas sobre a taxa de gestação em vacas receptoras de embriões. Ciência Animal Brasileira 11:280-291. 